\title{
PENGEMBANGAN INSTRUMEN PENGUKURAN KEPUASAN MAHASISWA DALAM PENINGKATAN MUTU LAYANAN PERGURUAN TINGGI
}

\author{
Rizki Mustikasari \\ STKIP PGRI Ponorogo \\ stkippgripo@yahoo.co.id
}

\begin{abstract}
Abstrak
Tujuan penelitian ini adalah mengembangkan instrument pengukuran kepuasan mahasiswa dalam peningkatan mutu layanan perguruan tinggi. Pengembangan instrument ini dimaksudkan agar institusi perguruan tinggi memiliki instrument pengukuran kepuasan mahasiswa yang valid dan reliable dalam mengukur kepuasan mahasiswa terhadap layanan administrative, dan kepuasan mahasiswa terhadap layanan proses pembelajaran. Jenis penelitian ini adalah Research and Development atau penelitian pengembangan. Proses pengembangan dilakukan dalam lima tahap, yaitu: analisis potensi dan masalah, perencanaan desain produk, uji coba produk, uji validitas dan reliabilitas produk, dan produksi masal. Pada instrument pengukuran kepuasan mahasiswa terhadap layanan administrative, scree plot menunjukan adanya perbedaan atau selisish yang sangat besar antara nilai igen faktor pertama dengan efaktor kedua. Sehingga instrument pengukuran kepuasan mahasiswa terhadap layanan administrative dinyatakan valid. Pada instrument pengukuran kepuasan mahasiswa terhadap layanan proses pembelajaran, diperoleh satu faktor yang memiliki nilai eigen di atas $1,00(>1,00)$. Sehingga dapat disimpulkan bahwa seluruh butir dalam instrumen pengukuran kepuasan mahasiswa terhadap proses pembelajaran hanya membentuk satu faktor bersama, yaitu faktor kepuasan terhadap proses pembelajaran. Sehingga isntrumen pengukuran kepuasan mahasiswa terhadap layanan proses pembelajaran dinyatakan valid. Uji reliabilitas instrument pengukuran kepuasan terhadap layanan administrative diperoleh nilai Cronbach's Alpha sebesar 0,843. Sehingga instrumen pengukuran kepuasan mahasiswa terhadap layanan administratif dinyatakan reliable. Uji reliabilitas instrument pengukuran kepuasan terhadap layanan proses pembelajaran diperoleh nilai Cronbach's Alpha sebesar 0,777. Dengan demikian instrumen pengukuran kegiatan ekstra dapat dinyatakan reliabel.
\end{abstract}

\section{PENDAHULUAN}

Kebutuhan masyarakat terhadap

pendidikan formal semakin meningkat,

khususnya pendidikan tinggi, menjadikan perguruan tinggi sebagai sektor strategis yang diharapkan dapat menghasilkan sumber daya manusia yang bermutu.Keadaan persaingan yang cukup kompetitif antar perguruan tinggi 
menuntut lembaga pendidikan mengembangkan komitmen setiap orang memperhatikan mutu pendidikan dan yang ada dalam lembaga untuk memenuhi kelembagaan sehingga mampu serta kebutuhan konsumen". unggul dalam persaingan tersebut.

Suatu institusi pendidikan tinggi, Agar dapat mencapai tujuan harus menerapkan konsep mengutamakan tersebut, perguruan tinggi harus kepuasan mahasiswa sebagai pelanggan melakukan langkah antisipasi guna dengan memberikan pelayanan terbaik. menghadapi persaingan yang semakin Beberapa bidang pelayanan yang harus kompetitif serta bertanggung jawab untuk dikembangkan secara berkelanjutan menggali dan meningkatkan segala aspek meliputi: kurikulum program studi, proses pelayanan yang dimiliki.Penelitian pembelajaran, sumber daya manusia mengenai berbagai permasalahan yang (dosen, pegawai, teknisi), mahasiswa, dihadapi perguruan tinggi dalam sarana dan prasarana, suasana akademik, kaitannya dengan pengukuran mutu jasa, penelitian serta publikasi, pengabdian penilaian dengan pendekatan akreditasi kepada masyarakat, manajemen lembaga, serta penilaian yang sifatnya langsung sistem informasi, dan kerjasama seperti tingkat gagal studi (DO), masa studi dan lainnya dianggap tidak cukup sehingga diperlukan paradigma baru sebagai indikator pengukuran mutu.

Keberhasilan institusi sebagai sebuah lembaga pendidikan sangat ditentukan oleh mutu pelayanan yang diberikan, dimana pelayanan yang bermutu dapat diidentifikasi melalui kepuasan pelanggan, dalam hal ini adalah mahasiswa. Cravens (Handayani, dkk., 2003) menyatakan "Untuk mencapai tingkat kepuasan yang tinggi, diperlukan adanya pemahaman tentang apa yang diinginkan oleh konsumen, dengan dalam/luar negeri.

Pengukuran mutu pelayanan merupakan elemen penting dalam menyediakan pelayanan yang lebih baik, lebih efisien, dan lebih efektif. Oleh karena itu, mutu pelayanan harus dimulai dari kebutuhan konsumen akan pelayanan dan berakhir pada persepsi konsumen akan mutu pelayanan yang diberikan. Pengukuran mutu pelayanan dalam bidang pendidikan tidak hanya dilihat dari pelayanan akademis, tetapi juga dilihat dari pelayanan nonakademis, di antaranya dalam hal administrasi perkuliahan. Pelayanan di sini dapat dipandang sebagai 
suatu tindakan yang dapat diberikan oleh seluruh jajaran institusi (pegawai, dosen, teknisi, sarana prasarana) kepada mahasiswa sebagai pelanggan internalnya.

Untuk mengetahui tingkat kepuasan mahasiswa sebagai konsumen internal, dibutuhkan suatu alat atau instrument pengukuran yang valid dan reliable. Instrumen tersebut dapat berupa angket yang berisi daftar pertanyaan yang berkaitan dengan kepuasan mahasiswa terhadap pelayanan akademis dan non akademis. Instrument yang valid adalah instrument yang dapat mengukur dengan benar dan semestinya. Sedangkan instrument yang reliable adalah instrument yang memberikan hasil yang tetap atau ajeg apabila diteskan berkali-kali. Berdasarkan alasan yang telah dikemukakan, peneliti merasa perlu dibuat instrument pengukuran untuk mengukur kepuasan mahasiswa terhadap layanan akademis dan non akademis yang valid dan reliable.

$\begin{array}{ccc}\text { Kepuasan } & \text { konsumen adalah } \\ \text { tingkat perasaan konsumen setelah }\end{array}$
membandingkan antara apa yang dia terima dan harapannya (Umar, 2005:65). Sejalan dengan pendapat tersebut, Philip Kotler dan Kevin Lane Keller menyatakan bahwa Kepuasan Konsumen adalah perasaan senang atau kecewa seseorang yang muncul setelah membandingkan kinerja (hasil) produk yang dipikirkan terhadap kinerja yang diharapkan (2007:177). Menurut Walker, et al. (2001:35) kepuasan pelanggan dapat didefinisikan sebagai suatu keadaan dimana kebutuhan, keinginan, dan harapan pelanggan dapat terpenuhi melalui produk yang dikonsumsi. Dalam penelitiannya, Oliver (2007:31) menjelaskan bahwa kepuasan pelanggan adalah bagian dari pemasaran dan memainkan peran penting di dalam pasar.

Memuaskan kebutuhan konsumen adalah keinginan setiap penyedia jasa layanan. Selain faktor penting bagi kelangsungan hidup penyedia jasa, memuaskan kebutuhan konsumen dapat meningkatkan keunggulan dalam persaingan. Churcill (2002:36) menyatakan bahwa kepuasan pelanggan memiliki reaksi secara keseluruhan antara harapan konsumsi dengan produk atau jasa di dasar persepsi reaksi, evaluasi dan psikologis.

Fandy Tjiptono

memberikan penjelasan tentang kepuasan konsumen sebagai berikut: a) Kepuasan atau ketidakpuasan pelanggan adalah respon pelanggan terhadap evaluasi 
ketidaksesuaian (disconfirmation) yang dirasakan antara harapan sebelumnya (atau norma kerja lainnya) dan kinerja aktual produk yang dirasakan setelah pemakaiannya; b) Mendefinisikan sebagai suatu tanggapan emosional pada evaluasi terhadap pengalaman konsumsi suatu produk atau jasa; c) Kepuasan pelanggan merupakan evaluasi purnabeli dimana alternatif yang dipilih sekurang-kurangnya sama atau melampaui harapan pelanggan, sedangkan ketidakpuasan timbul apabila hasil (outcome) tidak memenuhi harapan; d) Kepuasan adalah tingkatperasaan seseorang setelah membandingkan kinerja (hasil) yang ia rasakan dibandingkan dengan harapannya.

Hawkins dan Lonney dikutip dalam Tjiptono mengatakan atribut pembentuk kepuasan terdiri dari: Kesesuaian harapan, minat berkunjung kembali, dan kesediaan merekomendasikan (2004:101). Kepuasan mahasiswa terdiri dari kepuasan mahasiswa terhadap layanan administratif dan kepuasan terhadap layanan pembelajaran.

Layanan Administratif

Menurut Gronroos (dalam Ratminto dan Winarsih) mendefinisikan pelayanan adalah suatu aktivitas atau serangkaian aktivitas yang bersifat tidak kasat mata (tidak dapat diraba) yang terjadi akibat adanya interaksi antara konsumen dengan pegawai atau hal-hal lain yang disediakan oleh perusahaan pemberi pelayanan yang dimaksudkan untuk memecahkan permasalahan konsumen/pelanggan.

Kotler (2002: 85) mendefinisikan: Pelayanan adalah kegiatan atau manfaat yang ditawarkan oleh suatu pihak pada pihak yang lain yang pada dasarnya tidak menghasilkan kepemilikan. Lebih lanjut Philip Kotler memberikan lima determinan kualitas pelayanan yang dapatdirincikan sebagai berikut :

1) Kepercayaan atau kehandalan (Reliability): kemampuan untuk melaksanakanpelayanan yang dijanjikan dengan tepat dan terpercaya.

2) Daya tanggap (Responsiveness): kemampuan untuk membantu pelanggan danmemberikan jasa dengan cepat atau ketanggapan.

3) Jaminan (Assurance): pengetahuan dan kesopanan staf administrasi sertakemampuan mereka untuk menimbulkan kepercayaan dan keyakinan atau“assurance". 
4) Empati (Empathy): syarat untuk peduli, memberi perhatian pribadi bagipelanggan.

5) Berwujud (Tangibles): penampilan fasilitas fisik, perinstrumenan, personel danmedia komunikasi.

Sehubungan dengan hal diatas untuk menilai pelayanan publik yangberkualitas maka dapat di gunakan kriteria-kriteria atau faktor-faktor antara lain (zenithami: 2004: 48-50):

1) Tangibles (bukti Fisik), yaitu kemampuan suatu perusahaandalam menunjukkan eksistensinya kepada pihak eksternal. Penampilandan kemampuan sarana dan prasarana fisik perusahaan dankeadaan lingkungan sekitarnya adalah bukti nyata dari pelayanan yangdiberikan perusahaan.

2) Reliability (kehandalan) yaitu kemampuan untuk memberikan pelayanan yangdijanjikan dengan segera, akurat dan memuaskan. Kinerja harus sesuai denganharapan pelanggan yang berarti ketetapan waktu, pelayanan yang sama untuksemua pelanggan tanpa kesalahan, sikap simpatik dan akurasi yang tinggi.

3) Responsiveness (daya tanggap) yaitu kemampuan maskapai penerbangan untukmembantu dan memberikan pelayanan yang cepat (responsif) dan tepat kepadapara pelanggan dengan penyampaian informasi yang jelas. Membiarkanpelanggan menunggu tanpa adanya suatu alasan yang jelas menyebabkanpersepsi yang negatif dalam kualitas pelayanan.

4) Assurance (jaminan), adanya kepastian yaitu pengetahuan, kesopan santunandan kemampuan para pegawai perusahaan untuk menumbuhkan rasa percayapara pelanggan kepada pelayanan perusahaan yang memiliki:

a. Communication (komunikasi), yaitu secara terus menerus memberikaninformasi kepada pelanggan dalam bahasa dan penggunaan kata yang jelassehingga para pelanggan dapat dengan mudah mengerti di samping ituperusahaan hendaknya dapat secara cepat dan tanggap dalam menyikapikeluhan dan komplain yang dilakukan oleh pelanggan.

b. Credibility (kredibilitas), perlunya jaminan atas suatukepercayaan yang diberikan kepada pelanggan, believability atau sifatkejujuran. Menanamkan kepercayaan, 
memberikan kredibilitas yang baikbagi perusahaan pada masa yang akan datang.

c. Security (keamanan), adanya suatu kepercayaan yang tinggi dari pelangganakan pelayanan yang diterima. Tentunya pelayanan yang diberikanmemberikan suatu jaminan kepercayaan yang maksimal.

d. Competence (kompetensi) yaitu ketrampilan yang dimiliki dan dibutuhkanagar dalam memberikan pelayanan kepada pelanggan dapat dilaksanakandengan optimal.

e. Courtesy (sopan santun), dalam pelayanan adanya suatu nilai moral yangdimiliki oleh perusahaan dalam memberikan pelayanan kepada pelanggan.Jaminan akan kesopan santunan yang ditawarkan kepada pelanggan sesuaidengan kondisi dan situasi yang ada.

5) Empathy (empati), yaitu memberikan perhatian yang tulus dan bersifat individuatau pribadi yang diberikan kepada para pelanggan dengan berupayamemahami keinginan konsumen. Dimana suatu perusahaan diharapkanmemiliki pengertian dan pengetahuan tentang pelanggan, memahamikebutuhan pelanggan secara spesifik, serta memiliki waktu pengoprasian yangnyaman bagi pelanggan.

Dalam institusi prguruan tinggi, layanan terbagi dalam dua hal, yaitu: layanan administratif dan layanan proses pembelajaran. Sebelum menguraikan apakah admnistrasi institusi itu ada baiknya kita mengetaui terlebih dahulu apa yang dimaksud dengan "administrasi". Kata "administrasi" berasal dari bahasa Latin yang terdiri atas kata ad dan ministre. Kata ad mempunyai arti yang sama dengan to dalam bahasa inggris yang berarti "ke" atau "kepada". Dan ministre sama artinya dengan kata to serve atau toconduct yang berarti "melayani", atau "membantu" atau "mengarahkan". Dalamt bahasa Inggris to administer berarti pula "mengatur", "memelihara" (to like after) dan “mengarahkan” (Ngalim: 2004:1 ).

Sondang P. Siagan (1985:3), mendefinisikan administrasi sebagai keseluruhan proses kerjasama antara dua orang manusia atau lebih yang didasarkan atas rasionalitas tertentu untuk mencapai tujuan yang ditentukan sebelumnya. Ada beberapa hal yang terkandung dalam definisi di atas. Pertama, administrasi sebagai seni adalah suatu proses yang 
diketahui hanya permulaannya sedang akhirnya tidak ada. Kedua, administrasi mempunyai unsure tertentu, yaitu: adanya dua manusia atau lebih, adanya tujuan yang harus dilaksanakan, adanya tujuan yang harus dilaksanakan, adanya perinstrumenan dan perlengkapan untuk melaksanakan tugas-tugas itu.

Menurut Hamzah B. Uno hakikat pembelajaran memiliki perancangan atau perencanaan sebagai upaya untuk membelajarkan peserta didik ( 2010: 2). Hal ini mengindikasikan adanya unsur kesengajaan dalam proses pembelajaran, dan proses pembelajaran yang baik memiliki perencanaan matang agar peserta didik yang dibelajarkan mendapatkan tujuan dari proses pembelajaran.

Beberapa definisi di atas tentang dua suku kata yaitu pelayanan dan pembelajaran, dapat disimpulkan bahwa pelayanan pembelajaran adalah proses menyiapkan kebutuhan peserta didik dari pihak institusi perguruan tinggi melalui aktivitas-aktivitas kependidikan yang menggunakan berbagai fasilitas guna untuk meningkatkan kemampuannya secara kognitif, afektif dan psikomotorik sehingga dapat mencapai tujuan sekolah secara efektif dan efisien.
Dalam pelayanan proses pembalajaran, banyak aspek yang perlu diperhatikan. Aspek yang dimaksud adalah: Aspek pendekatan dalam pembelajaran, Aspek strategi dan taktik dalam pembelajaran, Aspek metode dan teknik dalam pembelajaran, Prosedur pembelajaran.

Instrumen Pengukuran

Pengukuran adalah serangkaian kegiatan yang bertujuan untuk menentukan nilai suatu besaran dalam bentuk angka (kwantitatif). Jadi mengukur adalah suatu proses mengaitkan angka secara empirik dan obyektif pada sifatsifat obyek atau kejadian nyata sehingga angka yang diperoleh tersebut dapat memberikan gambaran yang jelas mengenai obyek atau kejadian yang diukur.

Secara umum (sederhana) pengukuran adalah membandingkan suatu besaran yang tidak diketahui harganya dengan besaran lain yang telah diketahui nilainya. Pengukuran akan memberi arti penting bagi manusia untuk menggambarkan berbagai fenomena dalam bentuk kuantitatif atau angka. Lord Kelvin dalam Kaplan dan Norton (2010: 138) menyatakan bila kita dapat 
mengukur apa yang kita bicarakan serta menyatakan dalam bentuk angka, maka kita mengerti apa yang kita bicarakan. Tetapi bila kita tidak dapat mengukurnya dan menyatakannya dalam bentuk angka, maka pengetahuan anda tidak memuaskan atau bahkan mengecewakan.

Untuk mendapatkan hasil ukur yang tepat dan konsisten, perlu adanya suatu alat ukur yang valid dan reliable. Suatu instrument dikatakan valid jika alat ukur tersebut mampu dengan tepat mengukur apa yang hendak diukur. Menurut Hadi (1980:76) terdapat dua unsure penting yang tidak dapat dipisahkan dari prinsip validitas, yaitu kejituan dan ketelitian. Sedangkan instrument dikatakan reliable jika memiliki sifat konstan, stabil dan tepat. Dengan kata lain, jika instrument atau alat ukur tersebut digunakan pada subyek yang berlainan maka hasilnya akan sama. Bahkan jika digunakan dalam waktu yang berbeda, hasil pengukurannya akan sama. Spesifikasi instrument yang dirancang adalah:

1. Instrumen pengukuran kepuasan mahasiswa terhadap layanan administrative dan layanan proses pembelajaran berbentuk angket.
2. Angket pengukur kepuasan mahasiswa terhadap layanan administrative ditujukan untuk diisi oleh mahasiswa dan menilai keseluruhan layanan administrative yang diberikan oleh perguruan tinggi.

3. Angket pengukur kepuasan mahasiswa terhadap layanan proses pembelajaran ditujukan untuk diisi oleh mahasiswa dan diisi berdasarkan tanggapan mahasiswa terhadap dosen secara perorangan (individu).

4. Kedua instrument yang dikembangkan, disusun berdasarkan kisi-kisi yang dijabarkan dari aspek-aspek yang dibangkitkan dari teori.

\section{METODE PENELITIAN}

Langkah-langkah penelitian yang dipakai dalam penelitian pengembangan instrument pengukuran kepuasan mahasiswa terhadap layanan administrative dan proses pembelajaran ini menggunakan langkah-langkah penelitian dan pengembangan atau Research and Development $(R \& D)$. Ada beberapa macam langkah-langkah atau prosedur pengembangan dalam penelitian R\&D..Menurut Soenarto dalam Konsep Dasar dan Metode Penelitian Pengembangan (2013, 1827), dalam 
bidang pendidikan penelitian operasional field testing, (9) melakukan pengembangan bertujuan untuk revisi terhadap produk akhir, (10) menghasilkan produk yang dapat mendesiminasikan dan digunakan untuk memperbaiki dan mengimplementasikan produk (1983: meningkatkan kualitas pendidikan, 775).

mencakup berbagai aspek pendidikan : $\quad$ Prosedurnya cukup panjang jika pengembangan kurikulum, materi diikuti satu persatu setiap pembelajaran, metode pembelajaran, langkahnya.Namun tidak menutup media pembelajaran, manajemen kemungkinan hanya mengikuti beberapa laboratorium, pengembangan fasilitas, tahap pengembangan yang diperlukan evaluasi dan asesmen pembelajaran, uji saja.Pengurangan tahap terutama kompetensi dan sertifikasi. Strategi dimungkinkan apabila pengembangan penelitian pengembangan sesungguhnya dilakukan pada instrumen yang telah ada terdiri dari tiga komponen, yaitu 1) model dan bersifat memperbaharui atau atau desain pengembangan, 2) prosedur meningkatkan kualitas.Pengembangan pengembangan dan 3) validasi produk. produk tidak hanya merupakan membuat

Prosedur pengembangan yang instrumen dari awal tapi dapat juga sering menjadi pedomanbagi para peneliti memperbaharui instrumen yang telah ada antara lain prosedur Borg and Gall dan dengan memodifikasi atau prosedur pengembangan menurut Plomp. menggabungkan beberapa instrumen Prosedur pengembangan Borg \& Gall dengan ketentuan dan keperluan yang berbentuk linear dari tahap pertama tepat. sampai tahap terakhir, yaitu: (1) melakukan penelitian pendahuluan dan pengumpulan informasi, (2) melakukan percobaan, (3) mengembangkan bentuk produk awal, (4) melakukan preliminary testing, (5) melakukan revisi terhadap produk utama, (6) melakukan main field testing, (7) melakukan revisi terhadap produk operasional, (8) melakukan
Selain Borg dan Gall, langkahlangkah pengembangan juga dikemukakan oleh Sugiyono. Menurutnya penelitian dan pengembangan dapat dilakukan dengan analisis potensi dan masalah, mengumpulkan informasi dan studi literature, desain produk, validasi disain, perbaikan disain, uji coba produk, revisi produk, uji coba pemakaian, revisi 
produk, pembuatan produk secara diukur. Validitas ini digunakan dalam masal(2011:408). Dari kedua macam pengembangan instrument yang berbentuk langkah-langkah pengembangan, langkah- non tes. Validitas konstruk pada langkah pengembangan yang diciptakan penelitian ini diperoleh dengan dua tahap, oleh Sugiyono lebih sederhana yaitu validitas konstruk secara teoritis dan dibandingkan dengan langkah-langkah validitas konstruk empiris. Validitas pengembangan yang diciptakan oleh Borg konstruk secara teoritis diperoleh dengan dan Gall. Sehingga, langkah-langkah menyesuaikan instrumen yang dibuat penelitian tersebut lebih sesuai digunakan dengan teori yang mendasari variabeldalam penelitian dan pengembangan variabel dalam penelitian.Tahap validasi instrument pengukur kepuasan mahasiswa terhadap layanan administrative dan layanan proses pembelajaran.

Apabila ada rekomendasi untuk Berdasarkan uraian tersebut, perbaikan dari pakar, maka akan penelitian ini dapat dibagi menjadi dua tahapan.Tahap pertama mengumpulkan informasi tentang potensi dan masalah di lapangan. Selanjutnya potensi dan masalah dipergunakan untuk menyusun desain produk yang akan dihasilkan. Desain produk kemudian diterjemahkan kedalam bentuk angket untuk mengukur tingkat kepuasan mahasiswa terhadap layanan administrative dan proses pembelajaran. Kemudian media yang dikembangkan harus melalui tahap validasi konstruk.

Validitas konstruk menurut Gumbiner (2003:128) mempermasalahkan sejauhmana instrumen mampu mengukur konsep dari apa yang dirancang untuk dilakukan revisi terhadap instrumen yang dikembangkan. Jika sudah tidak perlu dilakukan revisi (tidak ada rekomendasi untuk perbaikan), berarti produk yang dihasilkan dianggap sudah layak diuji coba untuk mengetahui validitas konstruk secara empiris dan reliabilitasnya.Setelah semua tahapan dilakukan, dapat dipastikan kelayakan instrumen yang dikembangkan.

Analisis Potensi dan Masalah Pengembangan instrument pengukuran kepuasan mahasiswa terhadap layanan administrative dan layanan proses pembelajaran diawali dengan melakukan tahap penggalian potensi dan masalah. Analisis potensi dan masalah dilakukan 
untuk mengumpulkan informasi tentang proses pengukuran kepuasan mahasiswa yang pernah dilakukan sebelumnya serta meninjau kembali instrument pengukuran yang digunakan. Kegiatan ini dilakukan dalam dua tahap.Yaitu tahap studi pustaka dan tahap observasi lapangan.

Tahap studi pustaka dilakukan dengan mempelajari teori-teori tentang urgensi dilakukannya pengukuran tingkat kepuasan mahasiswa terhadap layanan administrative dan kepuasan mahasiswa terhadap layanan proses pembelajaran. Tahap observasi lapangan dilakukan untuk memperdalam hasil yang diperoleh dari tahap studi pustaka.Hasil observasi lapangan diperoleh dengan melakukan observasi terhadap dokumen hasil pengukuran kepuasan mahasiswa sebelumnya, meninjau kembali instrument yang digunakan, serta menggali informasi dari narasumber yang berkaitan dengan pengukuran tersebut.

Perencanaan Desain Produk

Produk yang akan dihasilkan dalam penelitian ini berupa Instrumen pengukuran tingkat kepuasan mahasiswa terhadap layanan administrative dan kepuasan mahasiswa terhadap layanan proses pembelajran. Instrumen tersebut dibuat berdasarkan kisi-kisi yang dibangun dari teori kepuasan pelanggan dan teori kepuasan mahasiswa.

Instrumen yang dikembangkan berupa angket dengan skala likert, dimana respondenhanya diminta untuk memberikan tanda centang $(\sqrt{ })$ pada skor yang menurutnya tepat. Dengan demikian pengguna dapat menggunakan instrument tersebut dengan mudah. Prosedur penyusunan instrument pengukuran kepuasan mahasiswa ini terdiri dari empat tahap: (a) Mengidentifikasi aspek-aspek yang diukur dari teori, (b) Menyusun kisikisi instrument berdasarkan aspek yang telah teridentifikasi, (c) menyusun instrument sesuai dengan kisi-kisi yang telah dibuat, (d) menguji validitas dan reliabilitas instrument yang dikembangkan.

Validasi Instrumen

Jenis validitas instrumen yang dikembangkan dalam penelitian ini adalah validitas konstruk.Konstruk adalah kerangka dari suatu konsep.Validitas konstruk menurut Gumbiner (2003:128) mempermasalahkan sejauh mana instrumen mampu mengukur konsep dari apa yang dirancang untuk diukur. Validitas ini digunakan dalam penyusunan instrument yang berbentuk non tes. Menurut Goodwin (1995: 98) suatu 
pengukuran behavioral dikatakan valid jika mengukur apa yang telah dirancang atau direncanakan untuk diukur. Dalam bukunya Gumbiner (2003: 127) menjelaskan bahwa ada sejumlah model validitas yang berbeda, antara lain validitas tampak (vace validity), validitas isi (content validity), validitas konstruk (construct validity), dan validitas prediktif (predictive validity).

Validitas konstruk pada penelitian ini diperoleh dengan dua tahap, yaitu validitas konstruk secara teoritis dan validitas konstruk secara empiris. Validitas konstruk secara teoritis diperoleh dengan menyesuaikan instrumen yang dibuat dengan teori yang mendasari variabel-variabel dalam penelitian. Tahap validasi ini dilakukan dengan konsultasi kepada pakar ( Dr. H Kasnadi). Berdasarkan saran dari pakar, instrumen yang dikembangkan telah dinyatakan sesuai dengan teori yang mendasari atau valid. Setelah dinyatakan valid oleh pakar, selanjutnya dilakukan uji coba terhadap instrumen tersebut

Uji coba dilakukan dalam dua tahap, yang pertama uji coba untuk mengetahui keterbacaan atau kemengertian responden terhadap pertanyaan dan pernyataan yang diberikan, kedua uji coba untuk mengetahui secara empiris apakah pertanyaan dan pernyataan yang disajikan benar-benar mengukur variabel yang hendak diukur. Uji coba pertama dilakukan dengan membagikan angket kepada 10 orang mahasiswa aktif, kemudian selain diminta untuk memberi pernyataan dan menjawab pertanyaan responden juga diminta untuk memberikan masukan untuk instrumen yang dikembangkan. Berdasarkan respon yang diberikan oleh responden, instrument yang dikembangkan mudah terbaca dan dimengerti sehingga tidak perlu dilakukan perbaikan.

Setelah mengetahui hasil dari uji keterbacaan dan pemahaman, instrument yang sedang dikembangkan kemudian diujicobakan kembali kepada mahasiswa aktif dalam jumlah yang lebih besar, kemudian menganalisa hasil yang diperoleh dengan menggunakan analisis faktor eksplanatory (ExplanatoryFactor Analysis) dengan bantuan program statistik SPSS. Dari hasil analisis ini akan didapatkan butir-butir yang valid dan yang gugur. Butir-butir yang gugur dibuang atau diperbaiki.Apabila butir yang valid sudah memenuhi jumlah butir yang direncanakan dalam alat ukur tersebut, 
maka butir yang gugur dapat dibuang, namun apabila belum memenuhi jumlah yang diharapkan maka butir yang gugur perlu diperbaiki.Untuk menentukan butir yang gugur dan yang layak dilakukan dengan tiga tahap perhitungan. Tahaptahap perhitungan tersebut adalah sebagai berikut:

a) Uji KMO (The Kaiser Meyer-Olkin) Uji KMO digunakan untuk mengetahui apakah variabel (butir) yang digunakan cukup akurat. Adapun kriteria penerimaan yang digunakan adalah apabila angka The Kaiser Meyer-Olkin (KMO) Measure of Sampling Adequasi dan Barlett's test lebih besar dari 0,5 (>0,5), dan probabilitas di bawah $0,05 \quad(<0,05)$, maka variabel (butir) tersebut dapat dianalisis lebih lanjut. Menurut Field (2009: 445) apabila tidak memenuhi kriteria tersebut, maka variabel (butir) tersebut harus dikeluarkan dari proses analisis.

b) Analisis Faktor (Factoring)

Analisis faktor adalah proses ekstraksi terhadap sekumpulan butir yang ada sehingga terbentuk menjadi satu atau lebih faktor. Berhentinya proses ekstraksi faktor didasarkan pada tolak ukur igen value. Suatu faktor bersama dianggap ada apabila igen value yang merupakan jumlah kuadrat muatan faktor lebih besar dari 1,00. Dalam penelitian ini analisis faktor dihitung dengan menggunakan metode ekstraksi Principal Componen Analysis.Adapun kriteria sebuah butir soal kedalam suatu faktor ditentukan oleh besarnya muatan faktor (loading factor) dan muatan bersama (communality) yang dimilikinya. Menurut Kerlinger (2006: 1005) menjelaskan bahwa suatu muatan faktor dianggap signifikan untuk mengungkap suatu faktor bila mempunyai muatan sebesar 0,30 atau lebih.

c) Rotasi Faktor (Factor Rotation) Faktor-faktor yang sudah diekstraksi harus dirotasi untuk memudahkan dalam interpretasi.Rotasi faktor dibuat sedemikian rupa sehingga mencapai pola muatan faktor yang sederhana.Rotasi dilakukan dengan mengubah pola muatan sehingga dapat diperoleh dukungan setiap faktor pada setiap butir atau variabel.Dalam penelitian ini rotasi analisis faktor menggunakan metode varimax. Metode ini mampu menghasilkan 
muatan-muatan faktor pada variabel yang dominan.

Reliabilitas Instrumen

Reliabilitas adalah tingkat keterpercayaan dari suatu instrument untuk mengukur variabel dalam suatu proses pengambilan data. Untuk mengetahui derajat reliabilitas suatu instrument, Allen dan Yen (1979: 72) dalam bukunya mengatakan " $A$ test is reliable if its observe scores are highly correlated with its true scores". Suatu tes dinyatakan reliabel jika (hasil tes) memiliki hubungan yang tinggi dengan skor sesungguhnya (true score). Menurut Goodwin ( 1995: 100) "Reliability is important because it enables one to have some confidance that the measure taken is close to the true measure". Reliabilitas itu penting karena dapat menunjukkan kepercayaan bahwa pengukuran yang diambil mirip dengan keadaan yang sesungguhnya. Penentuan reliabilitas instrumen yang dikembangkan dilakukan dengan bantuan program SPSS.

Reliabilitas ditunjukkan dengan angka atau koefisien.Semakin tinggi koefisien, menunjukkan semakin tinggi reliabilitas instrumen tersebut. Kriteria yang digunakan untuk menentukan tingkat reliabilitas yaitu apabila koefisien alpha

sama dengan 0,70 atau lebih (Linn, 1989: 106). Uji coba instrumen dilakukan pada mahasiswa aktif. Subyek diambil sejumlah 60 orang.

Hasil Pnelitian

Intrumen yang digunakan untuk menilai kepuasan terhadap layanan Administratif dikembangkan berdasarkan pengertian bahwa kepuasan adalah persepsi mahasiswa terhadap layanan yang sudah memenuhi harapannya, sehingga mahasiswa akan merasa tidak puas jika harapannya tidak tercapai. Pengertian tersebut dijabarkan ke dalamtiga aspek penilaian pada instrument kepuasan mahasiswa pada layanan administratif.

Adapun aspek-aspek kepuasan pelanggan yang dapat dijadikan untuk mengukur pelayanan yang diberikan menurut Kotler adalah sebagai berikut :Pelayanan yang memberikan rasa aman dan nyaman, Penerimaan informasi yang lengkap dan jelas, Kepuasan terhadap pelayanan yang diberikan para staf atau karyawan (dalam Tjiptono 1997:146). Aspek-aspek tersebut dijabarkan ke dalam dua belas indikator, kemudian dijabarkan lagi dalam bentuk instrument Setelah instrument tersusun, kemudian dilakukan 
pengujian untuk memastikan validitas dan reliabilitasnya.

Intrumen yang digunakan untuk menilai kepuasan terhadap proses pembelajaran dikembangkan berdasarkan pengertian bahwa kepuasan adalah persepsi mahasiswa terhadap layanan yang sudah memenuhi harapannya, sehingga mahasiswa akan merasa tidak puas jika harapannya tidak tercapai. Pengertian tersebut dijabarkan ke dalamempat aspek penilaian pada instrument kepuasan mahasiswa terhadap proses pembelajaran.

Aspek yang diamati pada pengukuran kepuasan mahasiswa terhadap layanan proses pembelajaran adalah: Aspek pendekatan dalam pembelajaran, aspek strategi dan taktik dalam pembelajaran, aspek metode danteknik dalam pembelajaran, dan prosedur pembelajaran. Keempat aspek tersebut dijabarkan ke dalam sepuluh indikator Kesepuluhindikator tersebut kemudian disusun dalam instrument berupa angket berskala likert. Angket tersebut ditujukan untuk mengukur kepuasan mahasiswa terhadap proses pembelajaran yang dilakukan oleh dosen, sehingga pengukuran dilakukan untuk masingmasing dosen. Setelah instrument tersusun, kemudian dilakukan pengujian untuk memastikan validitas dan reliabilitasnya. Hasil ujicoba instrument yang sedang dikembangkan secara terperinci akan dijelaskan pada bagian berikutnya.

Validitas Instrumen

Jenis validitas instrumen yang dikembangkan dalam penelitian ini adalah validitas konstruk.Konstruk adalah kerangka dari suatu konsep.Validitas konstruk menurut Gumbiner (2003:128) mempermasalahkan sejauh mana instrumen mampu mengukur konsep dari apa yang dirancang untuk diukur. Validitas ini digunakan dalam penyusunan instrument yang berbentuk non tes.

Validitas konstruk pada penelitian ini diperoleh dengan dua tahap, yaitu validitas konstruk secara teoritis dan validitas konstruk dari hasil uji coba. Validitas konstruk secara teoritis diperoleh dengan menyesuaikan instrumen yang dibuat dengan teori yang mendasari variabel-variabel dalam penelitian.Tahap validasi ini dilakukan dengan konsultasi kepada pakar (Dr. H Kasnadi).Berdasarkan saran dari pakar, instrumen yang dikembangkan telah dinyatakan sesuai dengan teori yang mendasari atau valid. Setelah dinyatakan 
valid oleh pakar, selanjutnya dilakukan uji coba terhadap instrumen tersebut

Uji coba dilakukan dalam dua tahap, yang pertama uji coba untuk mengetahui keterbacaan atau kemengertian responden terhadap pertanyaan dan pernyataan yang diberikan, kedua uji coba untuk mengetahui secara empiris apakah pertanyaan dan pernyataan yang disajikan benar-benar mengukur variabel yang hendak diukur. Uji coba pertama dilakukan dengan membagikan angket kepada 10 orang mahasiswa STKIP PGRI Ponorogo yang masih aktif, kemudian selain diminta untuk memberi pernyataan dan menjawab pertanyaan responden juga diminta untuk memberikan masukan untuk instrumen yang dikembangkan. Berdasarkan respon yang diberikan oleh responden, instrument yang dikembangkan mudah terbaca dan dimengerti sehingga tidak perlu dilakukan perbaikan.

Setelah mengetahui hasil dari uji keterbacaan dan pemahaman, instrument yang sedang dikembangkan kemudian diujicobakan kembali kepada mahasiswa aktif dalam jumlah yang lebih besar, kemudian menganalisa hasil yang diperoleh dengan menggunakan analisis faktor

eksplanatory

(ExplanatoryFactor Analysis) dengan bantuan program statistik SPSS. Dari hasil analisis ini akan didapatkan butir-butir yang valid dan yang gugur. Butir-butir yang gugur dibuang atau diperbaiki.Apabila butir yang valid sudah memenuhi jumlah butir yang direncanakan dalam alat ukur tersebut, maka butir yang gugur dapat dibuang, namun apabila belum memenuhi jumlah yang diharapkan maka butir yang gugur perlu diperbaiki.

Hasil analisis faktor dengan bantuan program SPSS untuk instrumen pengukuran kepuasan mahasiswa terhadap layanan administratif terlihat dalam tabel berikut:

\begin{tabular}{lll}
\hline KMO and Bartlett's Test \\
\hline $\begin{array}{ll}\text { Kaiser-Meyer-Olkin Measure } \\
\text { of Sampling Adequacy. }\end{array}$ & Appro \\
\hline \multirow{4}{*}{$\begin{array}{ll}\text { Bartlett's Test of } \\
\text { Sphericity }\end{array}$} & $\begin{array}{l}\text { X. Chi- } \\
\text { Square }\end{array}$ \\
\cline { 2 - 3 } & Df 23,413 \\
\cline { 2 - 3 } & Sig. $\quad, 000$ \\
\hline
\end{tabular}

Dari tabel tersebut diketahui nilai KMO MSA sebesar 0,724 (> 0,5) dengan taraf signifikan 0,000, artinya butir yang digunakan cukup akurat. Nilai MSA masing-masing butir pada tabel antiimage juga menunjukan nilai di atas 0,5. Dengan demikin keseluruhan butir yang 
terdapat dalam instrumen layak untuk dilakukan analisis faktor. Hasil ekstraksi faktor terlihat pada gambar berikut:

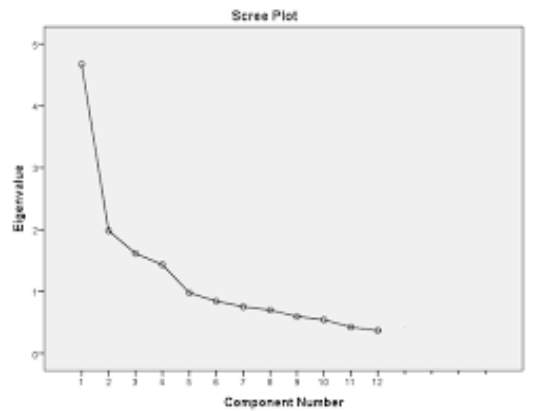

Gambar tersebut menunjukan terdapat 4 faktor yang memiliki nilai igen lebih besar dari 1,00. Sehingga dianggap ada 4 faktor bersama yang terbentuk.Hal ini tidak sesuai dengan jumlah faktor yang dirancang untuk diukur, karena instrumen ini dirancang hanya untuk mengukur kepuasan mahasiswa terhadap layanan administrative saja.Untuk memudahkan dalam interpretasi butir terhadap faktor yang terbentuk, dilakukan rotasi faktor dengan metode rotasi ortogonal varimax.Setelah dilakukan rotasi, jumlah komponen yang tereduksi tetap 4 komponen.

Untuk mengatasi kasus semacam ini Furr (2008: 74) mengatakan bahwa "we examine the scree plot to find a relatively large difference or drop in the plotted values". Kita menguji scree plot untuk menemukan perbedaan yang relatif besar atau tajam pada nilai yang diplotkan. Mengacu pada teori tersebut, instrumen pengukuran kepuasan mahasiswa terhadap layanan administrative yang dikembangkan sudah bisa dikatakan mengukur satu faktor. Karena scree plot menunjukan adanya perbedaan atau selisish yang sangat besar antara nilai igen faktor pertama dengan faktor kedua. Selisih tersebut jauh lebih besar bila dibandingkan dengan selisih atara nilai igen faktor kedua dengan faktor ketiga dan seterusnya.

Hasil analisis faktor untuk instrumen pengukuran kepuasan mahasiswa terhadap proses pembelajaran ditunjukan pada tabel berikut:

\begin{tabular}{|c|c|c|}
\hline \multicolumn{3}{|c|}{ KMO and Bartlett's Test } \\
\hline \multicolumn{2}{|c|}{$\begin{array}{l}\text { Kaiser-Meyer-Olkin Measure of } \\
\text { Sampling Adequacy. }\end{array}$} & ,645 \\
\hline \multirow{3}{*}{$\begin{array}{l}\text { Bartlett's Test of } \\
\text { Sphericity }\end{array}$} & $\begin{array}{l}\text { Approx. } \\
\text { Chi- } \\
\text { Square }\end{array}$ & $\begin{array}{l}46,87 \\
6\end{array}$ \\
\hline & Df & 6 \\
\hline & Sig. & ,000 \\
\hline
\end{tabular}

Nilai KMO MSA yang dihasilkan dari perhitungan adalah 0,645 (> 0,50) dengan nilai signifikansi 0,000 . Sehingga dapat disimpulkan bahwa butir yang digunakan cukup akurat. Pada tabel Anti Image, nilai MSA masing-masing butir instrumen menunjukan nilai di atas 0,50 (>0,50). Artinya keseluruhan butir dalam instrumen layak untuk dilakukan analisis 
faktor. Hasil ekstraksi faktor untuk instrumen tersebut. Kriteria yang instrumen pengukuran kepuasan digunakan untuk menentukan tingkat mahasiswa terhadap prosees perkuliahan reliabilitas yaitu apabila koefisien alpha terlihat pada gambar berikut:

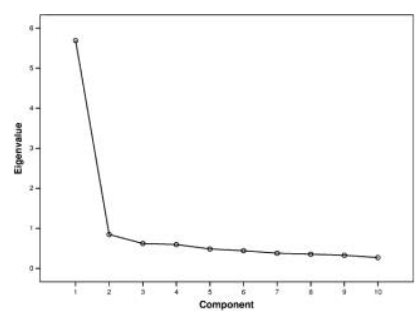
sama dengan 0,70 atau lebih (Linn, 1989: 106). Uji coba instrumen dilakukan pada mahasiswa yang masih aktif. Subyek diambil sejumlah 60 orang. Adapun hasil uji coba insrumen pengukuran kepuasan mahasiswa terhadap layanan

Gambar tersebut menunjukan bahwa terdapat satu faktor yang memiliki nilai eigen di atas $1,00(>1,00)$. Sehingga dapat disimpulkan bahwa seluruh butir dalam instrumen pengukuran kepuasan mahasiswa terhadap proses pembelajaran hanya membentuk satu faktor bersama, yaitu faktor kepuasan terhadap proses pembelajaran. Nilai loading factor masing-masing butir menunjukan angka yang lebih besar daripada 0,30 . Sehingga keseluruhan butir dinyatakan valid megukur kepuasan mahasiswa terhadap proses pembelajaran.

Reliabilitas Instrumen

$$
\text { Reliabilitas adalah tingkat }
$$
keterpercayaan dari suatu instrument untuk mengukur variabel dalam suatu proses pengambilan data. Reliabilitas ditunjukkan dengan angka atau koefisien.Semakin tinggi koefisien, menunjukkan semakin tinggi reliabilitas administrative adalah sebagai berikut:

\begin{tabular}{|c|c|}
\hline \multicolumn{2}{|c|}{ Reliability Statistics } \\
\hline Cronbach's Alpha & $\mathrm{N}$ of Items \\
\hline ,843 & 12 \\
\hline
\end{tabular}
pengukuran kepuasan mahasiswa terhadap layanan administratif tersebut diketahui nilai Cronbach's Alpha sebesar 0,843.Sehingga instrumen pengukuran kepuasan mahasiswa terhadap layanan administratif dinyatakan reliabel. Sedangkan hasil uji coba instrument pengukuran kepuasan mahasiswa terhadap proses pembelajaran dapat dilihat pada table berikut:

\begin{tabular}{ll}
\hline Reliability Statistics \\
\hline Cronbach's Alpha N of Items \\
\hline 777
\end{tabular}

Berdasarkan tabel reliabilitas instrumen kepuasan mahasiswa terhadap proses pembelajaran diketahui nilai Cronbach's Alpha yang diperoleh sebesar 0,777. Dengan demikian instrumen pengukuran kepuasan mahasiswa terhadap layanan 
proses pembelajaran dapat dinyatakan reliabel.

Instrumen pengukuran yang valid dan reliable dapat memberikan hasil pengukuran yang akurat dan dapat dipercaya. Hasil pengukuran kepuasan mahasiswa yang akurat dapat menjadi dasar dalam membangun lembaga yang unggul dan kompetitif.

\section{KESIMPULAN}

Dari penelitian yang telah dilakukan, diperoleh hasil uji validitas dan reliabiltas sebagai berikut:

1. Pada instrument pengukuran kepuasan mahasiswa terhadap layanan administrative, hasil analisis faktor menunjukkan bahwa terdapat 4 faktor yang memiliki nilai igen lebih besar dari 1,00. Sehingga dianggap ada 4 faktor bersama yang terbentuk. Setelah dilakukan rotasi, jumlah komponen yang tereduksi tetap 4 komponen.Mengacu pada teori Furr, instrumen pengukuran kepuasan mahasiswa terhadap layanan administrative yang dikembangkan sudah bisa dikatakan mengukur satu faktor. Karena scree plot menunjukan adanya perbedaan atau selisish yang sangat besar antara nilai igen faktor pertama dengan efaktor kedua. Selisih tersebut jauh lebih besar bila dibandingkan dengan selisih atara nilai igen faktor kedua dengan faktor ketiga dan seterusnya. Sehingga instrument pengukuran kepuasan mahasiswa terhadap layanan administrative dinyatakan valid.

2. Pada instrument pengukuran kepuasan mahasiswa terhadap layanan proses pembelajaran, diperoleh satu faktor yang memiliki nilai eigen di atas 1,00 $(>1,00)$. Sehingga dapat disimpulkan bahwa seluruh butir dalam instrumen pengukuran kepuasan mahasiswa terhadap proses pembelajaran hanya membentuk satu faktor bersama, yaitu faktor kepuasan terhadap proses pembelajaran. Sehingga isntrumen pengukuran kepuasan mahasiswa terhadap layanan proses pembelajaran dinyatakan valid.

3. Uji reliabilitas instrument pengukuran kepuasan terhadap layanan administrative diperoleh 
nilai Cronbach's Alpha sebesar 0,843. Sehingga instrumen pengukuran kepuasan mahasiswa terhadap layanan administratif dinyatakan reliable.

4. Uji reliabilitas instrument pengukuran kepuasan terhadap layanan proses pembelajaran diperoleh nilai Cronbach's Alpha sebesar 0,777. Dengan demikian instrumen pengukuran kegiatan ekstra dapat dinyatakan reliabel.

\section{DAFTAR PUSTAKA}

Allen, M.J \&Yen, W.M. 1979. Introduction to measurement theory. Belmont: Wadswort.

Amus soenarto.2013. Potret Pendidikan: "Masyarakat Tradisional, Modern, Dan Era Globalisasi". Jurnal Aktual. Volume.1,No.1, http://ejournal.lppm.unesa.ac.id/inde x.php/aktual/article/view/22.

Borg, W.R dan Gall, Meredith D. 1983. Educational Research: An Introduction. (Third Ed.).New York: Longman.

Daryanto, 2007, Evaluasi Pendidikan, Jakarta : Rineka Cipta

Furr, R.M., Verne. R. B. 2008. Psychometrics: an introduction. Singapore: SAGE

Gardner, M.P., 1990, Mood States and Consumer Behavior: Critical Review. Journal of Consumer Research, 12 (December): 281-300.
Goodwin, C.J. 1995. Research in psychology: Methods and design. New York: John Wiley\&Sons.

Gumbiner,J. 2003. Adolescent assessment. Hoboken: Wiley.

Hawkins, Best, Coney, 2004, Consumer Behavior, Building Marketing Strategy International Edition, Mc Graw Hill Companies, Inc

Kerlinger, F. N. 2006. Azas-Azas Penelitian Behavioral. (terjemahan simatupang, L.R \& Koesoemanto, J). Yogyakarta: Gajah Mada University Press. (Buku asli diterbitkan tahun 1964

Kotler, Philip. 2002. Manajemen Pemasaran. Jilid 1, Edisi Millenium. Penerjemah: Hendra Teguh S.E.,A.k. Jakarta. Prenhallindo

Kotler, Philip dan Armstrong, Gary. 2003. Principles of Marketing, 8th edition. Edisi Bahasa Indonesia ( alih bahasa oleh Damos Sihombing). Jakarta : Erlangga

Kotler ,Philip 2006. Marketing management, Indek eleven Edition pearson education, Inc.Upper Saddle River, New Jersey

Kotler, Philip Dan Kevin Lane Keller. 2007. Manajemen Pemasaran. Edisi Kedua Belas. Indeks : Jakarta

A.S Moenir. 1992. Manajemen Pelayanan Umum di Indonesia. Jakarta :Bumi Aksara.

Plomp, T. (1997) Educational and Training System Design. Nederlands: University of Twente Faculty of Educational Science and Technology.

Siagian, Sondang P. 1985. Filsafat administrasi. Jakarta : Gunung Mulia 
Sugiyono, Dr. Prof. 2009. Metode Penelitian Kuantitatif Kualitatif dan R\&D (edisi 8). Bandung: Alfabeta. Swastha, Basu. 2000. Azas-azas Marketing. Liberty. Yogyakarta.

Tjiptono, F. 1999. Kualitas Jasa Pengukuran, Keterbatasan dan Implikasi Manajerial. Usahawan No. 03/Thn. XXVIII/Maret.

Tjiptono, Fandy dan Anastasia Diana. 2003. Total Quality Manajemen. Edisi Revisi. Andy: Yogyakarta.

Umar, Husein. 1997. Study Kelayakan Bisnis. Edisi Ketiga. Gramedia Pustaka Utama : Jakarta.

Hamzah B. Uno, M. (2010). Teori motivasi dan pengukurannya. Jakarta: PT Bumi Aksara. Walker (2011)

Zeithaml, Valarie and A. Parasuraman 2004, Service Quality, MSI Relevant Knowledge Series, Cambridge, Massachusetts: Marketing Science Institute.

Zeithaml, V. A. \& Parasuraman, A. \& Malhotra 2002. E-S-QUAL A Multiple-Item Scale for Assessing Electronic Service Quality. New York: Free Press. 
Mustikasari, Pengembangan Instrumen... 